\title{
Serratia marcescens as a bacterial pathogen of Rhagoletis pomonella flies (Diptera: Tephritidae)
}

\author{
CAROL R. LAUZON ${ }^{1, *}$, Teresa G. BUSSERT ${ }^{1}$, RoBert E. SJOGREN ${ }^{2}$ and RonALD J. PROKOPY ${ }^{1}$ \\ ${ }^{1}$ Department of Entomology, University of Massachusetts, Amherst, MA 01003, USA \\ ${ }^{2}$ Department of Microbiology \& Molecular Genetics, University of Vermont, Burlington, VT 05405, USA
}

\begin{abstract}
Keywords. Tephritidae, apple maggot fly, Rhagoletis pomonella, microorganisms, Serratia marcescens, Pseudomonas, mortality, disease
\end{abstract}

\begin{abstract}
A nonpigmenting strain of Serratia marcescens Bizio isolated from dead and apparently diseased wild apple maggot flies, Rhagoletis pomonella (Walsh), was shown to be pathogenic to healthy apple maggot flies upon ingestion. The microorganism was detected in live adult alimentary canal organs four days post ingestion but produced death in some flies within $24 \mathrm{~h}$ when flies fed on a cell concentration of $4.7 \times 10^{4} \mathrm{cfu} / \mathrm{ml}$ and within $8 \mathrm{~h}$ when flies fed on filter-sterilized culture medium that previously contained a $21 \mathrm{~h}$ culture of $S$. marcescens. Increasing the cell concentration 10,000 fold did not lead to an increased rate of kill. Young flies (7-10 days old) were more susceptible to infection leading to death than were older flies (21-28 days old). The potential use of $S$. marcescens cells as control agents against apple maggot flies is negated by their pathogenicity to vertebrates; however, the potential use of toxic compounds produced by this strain of $S$. marcescens is discussed.
\end{abstract}

\section{INTRODUCTION}

Control of Rhagoletis pomonella (Walsh), a major apple pest in the United States, depends almost exclusively on the application of organophosphate insecticides azinphosmethyl or phosmet. Growing concerns about public health, environmental pollution, insecticide resistance, and rising costs associated with pest control press growers to consider alternative methods of pest control that are less invasive or more cost effective. The use of natural pathogens to cause epizootics is an alluring possibility. Specificity, persistence, and transovarial infection are a few characteristics of insect pathogens that make them attractive for insect pest management programs. Ample information exists regarding the success of certain natural pathogens for insect control, notably Bacillus thuringiensis used to control several genera of numerous insect orders, and Bacillus popilliae used to control Japanese Beetle, Popillia japonica Newman. Little is known about diseases in the apple maggot fly, and the information that does exist (e.g. Jacques et al., 1969; Fay, 1989) does not report specific causative agents and associated pathogenicity.

To begin to understand and evaluate any potential use of a pathogen for control of apple maggot fly, i.e. use of a toxic metabolite from a pathogen, we chose to examine the pathogenicity of a nonpigmenting strain of Serratia marcescens Bizio that was isolated earlier from dead and apparently diseased wild apple maggot flies and identified using standard methods (Brenner, 1992). Strains of $S$. marcescens have been reported to be recovered from other tephritids such as diseased Ceratitis capitata Weidemann and Dacus (Bactrocera) dorsalis Hendel flies
(Grimont \& Grimont, 1978) and these bacteria may possess some utility as insect control agents. With this idea in mind, we examined this microorganism for its ability to produce disease; that is, to become established within the fly, to resist the host's immune defenses, and to exploit the host to the point of disability and/or death. We sought to identify conditions for pathogenicity of $S$. marcescens to $R$. pomonella by feeding $S$. marcescens to adult $R$. pomonella and examining (1) the effects of two different ingested doses, (2) age-mortality relationships, (3) persistence and/or establishment of $S$. marcescens in alimentary canal organs of $R$. pomonella, and (4) the effect of the presence of $S$. marcescens on other bacterial populations present within alimentary canal organs of $R$. pomonella. We also demonstrated Koch's postulates and sought to determine if this strain produced any toxic metabolite(s) against $R$. pomonella.

\section{MATERIALS AND METHODS}

Bacterial cell preparation and fly feeding procedure. An $18 \mathrm{~h}$ culture of $S$. marcescens, obtained from dead $R$. pomonella eclosed from pupae collected in the field, was grown in $7 \mathrm{ml}$ trypticase soy broth (Difco Laboratories, Detroit, MI) (TSB) at $28^{\circ} \mathrm{C}$, not shaken, was placed in a Dynac ${ }^{\mathrm{TM}}$ centrifuge (ClayAdams Inc., Parsinnany, NJ) and spun at $5000 \mathrm{rpm}$ for $20 \mathrm{~min}$ at room temperature. The supernatant fluid was discarded, and the remaining pellet of bacterial cells was resuspended in $500 \mu 1$ of sterile distilled water $(\mathrm{pH} 7)$, which was just enough liquid to assist in the removal of the cells by micropipette. The cell-water suspension was enumerated by serial dilution using the spreadplate technique on prepoured trypticase soy agar (TSA) plates in triplicate. Colony-forming units were enumerated after $18 \mathrm{~h}$ of incubation at $30^{\circ} \mathrm{C}$. We determined that after $18 \mathrm{~h}$ of incubation in TSB, this strain of Serratia in culture had reached a density

\footnotetext{
* Current address. Department of Biological Sciences, California State University, Hayward, CA 94542, USA. E-mail: clauzon@csuhayward.edu; fax: (510)-885-4747.
} 
TABLE 1. Percent mortality of apple maggot flies (10-28 days old) caused by ingestion of $S$. marcescens recovered from dead S. marcescens-fed apple maggot flies.

\begin{tabular}{lcc}
\hline Treatment & No. tested & $\begin{array}{c}\text { Average percent mortality } \\
24 \mathrm{~h}\end{array}$ \\
\hline High dose $^{\mathrm{a}}$ & 58 & $50 \mathrm{a}$ \\
Low dose $^{\mathrm{b}}$ & 60 & $40 \mathrm{a}$ \\
Control & 60 & $5 \mathrm{~b}$ \\
\hline
\end{tabular}

${ }^{\text {a}}$ High dose $=4.7 \times 10^{8} \mathrm{cfu} / \mathrm{ml}$

${ }^{b}$ Low dose $=4.7 \times 10^{4} \mathrm{cfu} / \mathrm{ml}$

Values followed by the same lower case letter are not significantly different at $\mathrm{p}=0.05$ level according to least significant difference tests.

of $4.7 \times 10^{4}$ colony-forming units $(\mathrm{cfu}) / \mathrm{ml}$. Fifty $\mu 1$ of the cell suspension was then dispensed aseptically and equally onto 8 sterile paper disks ( $7 \mathrm{~mm}$ dia) made from Whatman No. 1 filter paper (Whatman Internat'l. Ltd, Maidstone, England) contained in a sterile Petri dish. Ten $\mu 1$ of a $10 \%$ yeast hydrolysate/sugar solution (fly food) was also added to each disk and mixed well with the bacterial cells. Apple maggot flies, eclosed from wildorigin pupae, were separated into groups based on age and were starved of protein and sugar for $18 \mathrm{~h}$. Flies were then placed individually into Petri dishes containing the bacterial cells on paper disks and were allowed to feed. Flies that fed only on the yeast hydrolysate/sugar solution (plus $50 \mu 1$ sterile $\mathrm{dH}_{2} 0$ ) on paper disks served as controls. Flies were watched carefully and, after all flies had fed and displayed distended abdomens, the flies were removed and placed in plexiglass-wire cages containing fresh water, sugar, and protein. Percent mortality was recorded after 24 and $120 \mathrm{~h}$

High and low dose tests. A concentration of $4.7 \times 10^{8}$ $\mathrm{cfu} / \mathrm{ml}$, obtained by dilution technique, was chosen arbitrarily and considered to be a "high" dose of $S$. marcescens, while a concentration of $4.7 \times 10^{4} \mathrm{cfu} / \mathrm{ml}$ was considered to be a "low" dose of the bacterial cells. Recall that this low dose did cause mortality within $24 \mathrm{~h}$ (Table 1.). From this point onward, high and low doses refer to these cell concentrations respectively. Four groups of 15 adult $R$. pomonella were fed the high dose and 4 groups of 15 adult $R$. pomonella were fed the low dose of $S$. marcescens following the disk method described above. Four groups of 15 adult $R$. pomonella were fed yeast hydrolysate/sugar and served as control groups. Percent mortality was recorded at 24 and $120 \mathrm{~h}$.

Age-mortality relationship tests. High and low doses of $S$. marcescens were fed to $R$. pomonella considered to be young (7-10 days old) and old (21-28 days old). Six cages for each age and dose (15 flies per cage) were tested using the paper disk method described above. "Young" and "old" fly groups serving as control groups $(\mathrm{N}=90)$ were given only yeast hydrolysate/ sugar. Percent mortality was recorded at 24 and $120 \mathrm{~h}$.

Detection, establishment and persistence of Serratia marcescens within the host. $R$. pomonella (7-10 days old) were fed a dose of $4.7 \times 10^{4} \mathrm{cfu} / \mathrm{ml}$ and were sacrificed $1-2 \mathrm{~min}, 15 \mathrm{~min}$, $30 \mathrm{~min}, 1 \mathrm{~h}, 24 \mathrm{~h}$, and $4 \mathrm{~d}$ post-feeding while at the same time parts of their alimentary canal tract (esophageal bulb, crop, and a section of midgut) were removed aseptically from each fly. The organs were placed individually into $7 \mathrm{ml}$ of TSB and incubated for $18-24 \mathrm{~h}$ at $28^{\circ} \mathrm{C}$. The cultures were streaked individually onto TSA to obtain pure colonies, incubated at $28^{\circ} \mathrm{C}$, and bacterial colonies were subcultured onto biochemical media for identification. The API 20E (Analytab Products, Inc., Plainview, NY) microbiological identification system was also used as part of the identification process. $R$. pomonella that fed on yeast hydrolysate/sugar alone were likewise dissected at the same time intervals and served as control groups. The presence, not quantity, of $S$. marcescens in the removed parts of the alimentary canal was recorded. Recovered $S$. marcescens were fed to small groups (10) of flies (6) ranging in age between 10 to 28 days old to confirm Koch's postulates.

Toxicity tests using $\boldsymbol{S}$. marcescens supernatant. A $21 \mathrm{~h}$ culture of $S$. marcescens grown in TSB and centrifuged at 5000 rpm for $15 \mathrm{~min}$ at $4^{\circ} \mathrm{C}$. The supernatant was removed and filtersterilized using a $0.22 \mu \mathrm{m}$ filter (Acrodisc, Gelman Sciences, Ann Arbor, MI). A sample of the supernatant was placed into TSB which was incubated overnight and observed for any bacterial growth. Lack of growth confirmed successful filter sterilization. Fifty $\mu$ l of sterile supernatant was applied to sterile paper disks as described earlier. Adult $R$. pomonella "young" and "old" flies, as described earlier, were allowed to feed on the soaked disks contained in a sterile Petri dish. Once the flies were observed to have fed and their abdomens were distended, the flies were individually removed and placed by age into separate cages containing fresh food and water. Preliminary feeding tests revealed that some flies that fed on the supernatant died just hours after feeding. Therefore, percent mortality was recorded at 8 and $24 \mathrm{~h}$.

Statistical analysis. Data acquired from all studies were analyzed using the Statistix(C) Analytical Software for analysis of variance tests (SAS Institute, 1985).

\section{RESULTS}

Preliminary tests showed that a cell concentration of 4.7 $\times 10^{4} \mathrm{cfu} / \mathrm{ml}$ produced death in approximately $48 \%$ of flies that were approximately 14 days old. Tests were then designed to determine a concentration of this $S$. marcescens needed to produce approximately $50 \%$ death of flies within a predetermined time period for a broad age range of flies. These tests showed that a cell concentration of $4.7 \times 10^{4} \mathrm{cfu} / \mathrm{ml}$ produced death in $43 \%$ of the flies after $24 \mathrm{~h}$ with no appreciable additional death after $120 \mathrm{~h}$ (data not shown). All control flies (not exposed to the pathogen) were alive at $120 \mathrm{~h}$.

Flies that fed on the two different concentrations of $S$. marcescens, $4.7 \times 10^{4} \mathrm{cfu} / \mathrm{ml}$ and $4.7 \times 10^{8} \mathrm{cfu} / \mathrm{ml} \mathrm{respec}-$ tively, produced nearly identical results (Table 1 ). There was no significant difference in fly mortality between concentrations. However, significant differences in mortality did occur between fly ages; younger flies were significantly more susceptible to infection and death than older flies at each concentration (Table 2).

To determine the presence and persistence of $S$. marcescens within infected $R$. pomonella, flies fed on bacterial suspensions and alimentary canal organs were sampled for S. marcescens starting at 1-2 $\mathrm{min}$ and ending at 4 days post-ingestion. $S$. marcescens were recovered 1-2 min after feeding and until the end of the study (Table 3 ). By day's end of the fourth day (post-ingestion), only 30 percent of the infected flies remained alive and of these $30 \%, 66 \%$ harbored $S$. marcescens. The control flies did not harbor any Serratia sp. in samples of their alimentary canals (data not shown).

Microorganisms present within the alimentary canal of $R$. pomonella maintained in the laboratory before experi- 
TABLE 2. Percent mortality of young and old apple maggot flies caused by ingestion of two different concentrations of Serratia marcescens.

\begin{tabular}{|c|c|c|c|c|c|}
\hline \multirow{3}{*}{ Treatment } & \multirow{3}{*}{$\begin{array}{l}\text { No. } \\
\text { tested }\end{array}$} & \multicolumn{4}{|c|}{ Average percent mortality } \\
\hline & & \multicolumn{2}{|c|}{$\begin{array}{c}\text { Young } \\
\text { (7-10 days old) }\end{array}$} & \multicolumn{2}{|c|}{$\begin{array}{c}\text { Old } \\
(21-28 \text { days old })\end{array}$} \\
\hline & & $24 \mathrm{~h}$ & $120 \mathrm{~h}$ & $24 \mathrm{~h}$ & $120 \mathrm{~h}$ \\
\hline High dose $\mathrm{e}^{\mathrm{a}}$ & 90 & $30 \mathrm{a}$ & $33 a$ & $12 b$ & $20 \mathrm{~b}$ \\
\hline Low dose $\mathrm{e}^{b}$ & 90 & $27 \mathrm{a}$ & $31 \mathrm{a}$ & $18 \mathrm{~b}$ & $20 \mathrm{~b}$ \\
\hline Control (uninfected) & 90 & $6 c$ & $6 c$ & $10 \mathrm{bc}$ & $15 b$ \\
\hline
\end{tabular}

${ }^{\text {a }}$ High dose $=4.7 \times 10^{8} \mathrm{cfu} / \mathrm{ml}$

${ }^{b}$ Low dose $=4.7 \times 10^{4} \mathrm{cfu} / \mathrm{ml}$

Values followed by a different lower case letter are significantly different at $\mathrm{p}=0.05$ level according to least significant difference tests.

mentation were primarily Pseudomonas sp., Alcaligenes sp., and Acinetobacter sp. The control flies were found to contain large numbers of Pseudomonas sp., and lesser numbers of Alcaligenes sp. and Acinetobacter sp. (nonfermenters), with very few Enterobacter spp. and Klebsiella spp. (butylene glycol fermenters) throughout the study. After feeding on S. marcescens, however, infected flies showed an increase in isolation of the number of bacterial species belonging to the family Enterobacteriaceae (Table 4). In these test flies, Klebsiella sp. dominated, followed closely by Enterobacter sp., with only 1 Pseudomonas sp. and no Alcaligenes or Acinetobacter sp. recovered. $S$. marcescens re-isolated from test flies was subsequently used to test Koch's Postulates. We determined that, indeed, this strain of $S$. marcescens was responsible for apple maggot fly death (data not shown) in mortality studies.

The supernatant from a $21 \mathrm{~h}$ old culture of $S$. marcescens was highly toxic to flies, killing on average $59 \%$ of the young flies within $8 \mathrm{~h}$ and $72 \%$ within $24 \mathrm{~h}$. Eighty percent of old flies were dead within $24 \mathrm{~h}$ (Table 5). There was no difference in mortality in relation to age.

\section{DISCUSSION}

Our findings indicate that a nonpigmenting strain of $S$.

TABLE 4. Demonstrated shift in bacterial species in the alimentary canals of Rhagoletis pomonella after being infected with Serratia marcescens.

\begin{tabular}{lccc}
\hline & \multicolumn{3}{c}{$\begin{array}{c}\text { Number of bacterial species recovered from } \\
\text { alimentary canal organs }\end{array}$} \\
\cline { 2 - 4 } & \multicolumn{4}{c}{ Classification } & $\begin{array}{c}\text { Before } \\
\text { infection }\end{array}$ & $\begin{array}{c}\text { After } \\
\text { infection }\end{array}$ \\
\hline Pseudomonas spp. & $\mathrm{NF}$ & 3 & 1 \\
Acinetobacter sp. & $\mathrm{NF}$ & 1 & 0 \\
Alcaligenes sp. & $\mathrm{NF}$ & 1 & 0 \\
Klebsiella sp.* & $\mathrm{F}$ & 1 & 3 \\
Serratia sp.* & $\mathrm{F}$ & 0 & 2 \\
Enterobacter sp.* & $\mathrm{F}$ & 0 & 2 \\
\hline
\end{tabular}

*Members of the family Enterobacteriaceae

$\mathrm{NF}=$ Nonfermenter

$\mathrm{F}=$ Fermenter
TABLE 3. Establishment and persistence of Serratia marcescens in laboratory-tested Rhagoletis pomonella.

\begin{tabular}{|c|c|c|c|c|c|}
\hline \multirow{2}{*}{$\begin{array}{l}\text { Time } \\
\text { elapsed from } \\
\text { inoculation } \\
\text { until } \\
\text { dissection }\end{array}$} & \multirow[t]{2}{*}{$\begin{array}{l}\text { Group } \\
\text { dissected }\end{array}$} & \multicolumn{4}{|c|}{$\begin{array}{l}\text { Identified bacterial isolates } \\
\text { recovered by dissection }\end{array}$} \\
\hline & & $\mathrm{Sm}^{\mathrm{a}}$ & $\begin{array}{l}\text { Other } \\
\text { Entero- } \\
\text { bacte- } \\
\text { riaceae }\end{array}$ & $\mathrm{PS}^{\mathrm{b}}$ & $\begin{array}{l}\text { Other } \\
\text { aerobes }\end{array}$ \\
\hline $1-2 \mathrm{~min}$ & $\begin{array}{l}\text { Treatment } \\
\text { Control }^{\mathrm{g}}\end{array}$ & $\begin{array}{c}\mathrm{T}^{\mathrm{d}} \\
\mathrm{Nr}^{\mathrm{h}}\end{array}$ & $\begin{array}{l}\mathrm{F}^{\mathrm{e}} \\
\mathrm{F}\end{array}$ & $\begin{array}{l}D^{f} \\
D\end{array}$ & $\begin{array}{l}F \\
F\end{array}$ \\
\hline $15 \mathrm{~min}$ & $\begin{array}{l}\text { Treatment } \\
\text { Control }\end{array}$ & $\begin{array}{c}\mathrm{T} \\
\mathrm{Nr}\end{array}$ & $\begin{array}{l}\mathrm{F} \\
\mathrm{F}\end{array}$ & $\begin{array}{l}\mathrm{D} \\
\mathrm{D}\end{array}$ & $\begin{array}{l}\mathrm{F} \\
\mathrm{F}\end{array}$ \\
\hline $30 \mathrm{~min}$ & $\begin{array}{l}\text { Treatment } \\
\text { Control }\end{array}$ & $\begin{array}{c}\mathrm{T} \\
\mathrm{Nr}\end{array}$ & $\begin{array}{l}\mathrm{D} \\
\mathrm{F}\end{array}$ & $\begin{array}{l}\mathrm{F} \\
\mathrm{D}\end{array}$ & $\begin{array}{l}\mathrm{T} \\
\mathrm{f}\end{array}$ \\
\hline $1 \mathrm{~h}$ & $\begin{array}{l}\text { Treatment } \\
\text { Control }\end{array}$ & $\begin{array}{l}\mathrm{F} \\
\mathrm{Nr}\end{array}$ & $\begin{array}{l}\mathrm{D} \\
\mathrm{F}\end{array}$ & $\begin{array}{l}\mathrm{F} \\
\mathrm{D}\end{array}$ & $\begin{array}{c}\mathrm{Nr} \\
\mathrm{F}\end{array}$ \\
\hline $24 \mathrm{~h}$ & $\begin{array}{l}\text { Treatment } \\
\text { Control }\end{array}$ & $\begin{array}{l}\mathrm{F} \\
\mathrm{Nr}\end{array}$ & $\begin{array}{l}\mathrm{D} \\
\mathrm{F}\end{array}$ & $\begin{array}{l}\mathrm{T} \\
\mathrm{D}\end{array}$ & $\begin{array}{l}\mathrm{F} \\
\mathrm{F}\end{array}$ \\
\hline $4 \mathrm{~d}$ & $\begin{array}{c}\text { Treatment } \\
\text { Control }\end{array}$ & $\begin{array}{c}\mathrm{T} \\
\mathrm{Nr}\end{array}$ & $\begin{array}{l}\mathrm{D} \\
\mathrm{F}\end{array}$ & $\begin{array}{l}\text { F } \\
D\end{array}$ & $\begin{array}{c}\mathrm{Nr} \\
\mathrm{F}\end{array}$ \\
\hline $\begin{array}{l}{ }^{\mathrm{a}} \mathrm{Sm}=\text { Serrati } \\
{ }^{\mathrm{b}} \mathrm{PS}=\text { Pseudor } \\
{ }^{\mathrm{c}} \mathrm{Treatment}= \\
\text { R. pomonella } \\
{ }^{\mathrm{d}} \mathrm{T}=\text { trace bac } \\
\text { recovered }\end{array}$ & $\begin{array}{l}\text { marcescens } \\
\text { onas sp. } \\
\text { marcescens-fed } \\
\text { rial species }\end{array}$ & & \multicolumn{3}{|c|}{$\begin{array}{l}{ }^{\mathrm{e}} \mathrm{F}=\text { few bacterial } \\
\text { species recovered } \\
\mathrm{f} \mathrm{D}=\text { dominant bacterial } \\
\text { species recovered } \\
{ }^{\mathrm{g} C o n t r o l}=\text { normal }, \text { pro- } \\
\text { tein }- \text { fed } R \text {. pomonella } \\
{ }^{h} \mathrm{Nr}=\text { not recovered }\end{array}$} \\
\hline
\end{tabular}

marcescens isolated from diseased and/or dead apple maggot flies kills, on average, $40 \%$ of test flies (10-28 days old) within $24 \mathrm{~h}$ post-ingestion at a concentration of $4.7 \times 10^{4} \mathrm{cfu} / \mathrm{ml}$. Increasing the number of cells ingested by the flies 10,000 fold did not lead to a substantial increase in the rate or amount of kill. There may be at least five possible explanations for this occurrence: (1) the rapidity of kill eliminates or disguises any obvious dosage effect, (2) the doses tested are actually two closely-aligned points on a dose-response curve, (3) virulence is related to an exotoxin produced by the bacteria, whose lethal concentration is not based solely on cellular number, (4) enough $S$. marcescens were digested by some flies to release toxic or lethal amounts of Lipid A (endotoxin) (Atlas, 1988) or (5) cells entered the insects' hemolymph via small wounds or other entrance sites during feeding. Further investigation is needed to evaluate these possibilities and/or any other subtle effects of dosage.

TABLE 5. Average percent mortality of young and old $R$. pomonella flies after ingestion of supernatant from a $21 \mathrm{~h}$ culture of Serratia marcescens.

\begin{tabular}{lcccccc}
\hline \multirow{2}{*}{ Treatment } & & \multicolumn{3}{c}{ Average percent mortality } \\
\cline { 3 - 4 } & No. & \multicolumn{2}{c}{ Young } & & \multicolumn{2}{c}{ Old } \\
& tested & \multicolumn{2}{c}{$(7-10$ days old $)$} & & \multicolumn{2}{c}{$(21-28$ days old $)$} \\
\cline { 3 - 4 } \cline { 3 - 6 } & & $8 \mathrm{~h}$ & $24 \mathrm{~h}$ & & $8 \mathrm{~h}$ & $24 \mathrm{~h}$ \\
\hline Supernatant & 90 & $59 \mathrm{a}$ & $72 \mathrm{a}$ & & $60 \mathrm{a}$ & $80 \mathrm{a}$ \\
Control & 90 & $0 \mathrm{~b}$ & $0 \mathrm{~b}$ & & $0 \mathrm{~b}$ & $0.11 \mathrm{~b}$ \\
\hline
\end{tabular}

Values followed by a different lower case letter are significantly different at $\mathrm{p}=0.05$ level according to least significant difference tests. 
Young $R$. pomonella appeared to be more sensitive to the presence of this bacterial pathogen than older more mature flies (Table 2). This is contrary to studies that suggest decreased enzyme action and immune response are characteristic of older mature flies (Christensen et al., 1986, Jianyong et al., 1992), making them more sensitive to the effects of bacterial pathogens. In addition, during the course of our study a few of the test flies (young and old) did not appear to be adversely affected upon exposure to the pathogen. This suggests that those flies were insensitive to the pathogen's presence or that some protective mechanism was present in such flies (i.e. induction of bactericidal peptides) but not in the majority of the fly population.

Several studies exist that describe acquired humoral immunity against bacteria and toxins in insects (e.g. Krieg, 1987), although Chadwick (1971) found that $S$. marcescens survived treatment with immunized hemolymph. In our experiments, such a protective mechanism is not known but merits further investigation. In addition, tighter age-dependency experiments should be conducted with companion microbiological and immunological analyses. It is also possible that these flies did not ingest or feed as much as the other flies, however, this is unlikely as each fly was observed to feed and only flies with extended abdomens post-feeding were used for the study.

We have also shown that $S$. marcescens was responsible for the death of $R$. pomonella flies by fulfilling the requirements of Koch's postulates. We isolated continuously this strain of $S$. marcescens from dead flies and used these cultures to reinfect additional flies whom also died. The gut environment of the fly appears to favor growth of $S$. marcescens and possibly other bacteria once introduced. Several different tephritid pest species possess few bacteria on eclosion (Lauzon et al., 2000, unpublished). It is likely that the first bacteria that arrive to or are already present in the gut that can tolerate or thrive under gut conditions are those that become established. Enteric bacteria, Enterobacter spp. and Klebsiella spp. are isolated repeatedly from the alimentary canal organs of $R$. pomonella despite the numerous different types of bacteria and fungi that these flies consume while feeding on natural food sources, such as fecal material (e.g. Lauzon et al., 1998, 2000). Serratia spp., Enterobacter and Klebsiella spp. are all members of the family Enterobacteriaceae. Perhaps the gut environment is exceptionally supportive of these types of bacteria. In addition, a dramatic shift in the kinds and numbers of bacteria within the alimentary canal of flies infected with $S$. marcescens suggests that fundamental changes are occurring within the flies when they are exposed to this pathogen. The exact mechanism for this shift is not known but could be related to $\mathrm{pH}$ effects on bacterial growth. In preliminary experiments, we demonstrated that $S$. marcescens grows well in an acidic ( $\mathrm{pH} 5.0$ ) environment (data not shown). Pseudomonas spp. and related bacteria, which were found to be dominant inhabitants of alimentary canals of laboratory-maintained apple maggot flies before testing, favor utilization of amino acids as an energy source and are sensitive to acidic $\mathrm{pH}$. Conversely, Serratia spp. are rapid fermenters of carbohydrates. The rapid utilization of carbohydrates results in the release of small amounts of acids from the breakdown of glucose, and appear to tolerate an acidic environment very well. A pH shift downward would tend to favor bacteria tolerant of an acidic environment; however, further work is necessary before a more definitive statement can be made as to why a population shift occurred. Kodama \& Nakasuji (1971) described a situation where the presence of Streptococcus faecalis and $S$. faecium in the midgut of silkworms enhances the pathogenicity of Serratia piscatorum by lowering the midgut $\mathrm{pH}$ to one that favors the growth of the Serratia sp. Several investigators have reported numerous factors that affect susceptibility of insects to bacterial infection, including age (Beegle et al., 1981), plant allelochemical-induced stress (Felton \& Dahlman, 1984), diet (James \& Lighthart, 1992), and general changes of microbiotia within insects housed in laboratories (Lighthart, 1988). Whatever the explanation, the strain of $S$. marcescens tested here does kill $R$. pomonella, which indicates that further study is merited to understand the nature of pathogenicity associated with this strain of S. marcescens.

$S$. marcescens has been reported as a pathogen of several economically important insect pests such as the boll weevil, Anthonomus grandis Boheman (Ourth \& Smalley, 1980), the tobacco hornworm, Manduca sexta (Linnaeus) (Dunn \& Drake, 1983), and the house fly, Musca domestica Linnaeus (Benoit et al., 1990), as well as beneficial arthropods such as the predatory mite Metaseiulus occidentalis (Nesbitt) (Lighthart et al., 1988), and the honey bee, Apis mellifera Linnaeus (El Sanousi et al., 1987). S. marcescens also has been reported as an insect pathogen of moderate virulence that causes a fatal septicemia after penetration through the insect's gut wall and subsequent invasion of the hemocoel (Lysenko, 1985; Krieg, 1987). Though pathogenicity has been reported for several insect species, most methodologies used include only injection of Serratia sp. into the insect (Steinhaus, 1963) rather than introduction of the bacteria into the insect through ingestion. Ingestion of $S$. marcescens is generally seen as of little consequence to insects (e.g. Podgwaite \& Cosenza, 1976), however, Bracken \& Buchner (1967) did show that the ichneumonid parasitoid Exeristes comstockil (Cresson) acquires enough $S$. marcescens from its larval form to cause a fatal septicemia in its own and other adults.

S. marcescens is ubiquitous in nature (Brenner, 1992), but its presence and persistence is not well characterized and it is not often recovered from wild insects (Steinhaus, 1959; Krieg, 1987). Studies aimed at examining further the ecology of $S$. marcescens are discouraged because the pathogenicity of $S$. marcescens to humans, other vertebrates, and beneficial insects prevents widespread use of this microorganism per se to control insect pests. Our data indicate, however, that this strain of $S$. marcescens produces a metabolite(s) toxic to apple maggot flies, sug- 
gesting the possible use of the toxic metabolite(s) produced by $S$. marcescens in apple maggot fly control strategies.

Toxins or proteases secreted by Serratia sp. may facilitate entrance of the bacteria into the hemocoel. At present, some 11 proteases have been described as being produced by several different strains of $S$. marcescens (e.g. Brenner, 1992), including chitinases (Lysenko, 1976). Poinar et al. (1979) found that $S$. marcescens was capable of entering the hemocoel in tsetse flies, which died soon after from fatal septicemia. Also, Asano et al. (1999) determined that synergistic effects occurred when supernatant from a culture of Serratia marcescens was used in conjunction with Bacillus thuringiensis Cry1C toxin. It remains to be determined if our strain of $S$. marcescens enters the hemocoel of apple maggot flies and if this entrance is facilitated by one or more toxin(s); however, samples of several midguts of $R$. pomonella that died in our study looked partially or completely disintegrated. Perhaps the condition of the midgut was due to autolysis and/or proteinases produced by Serratia growing post mortem. Serratia spp. typically produce compounds other than proteases and possibly, these compounds were produced by our strain that feasibly poisoned the flies. These compounds would include peptides, acids and alcohols (e.g. Brenner, 1992). Current studies are underway to characterize the candidate toxin(s) produced by this strain of $S$. marcescens. Thus far, we have conducted experimentation aimed to characterize the nature of the supernatant (CRL et al., unpubl.) and isolate any toxic components. Our efforts show some promising preliminary findings including indication that flies find toxic fractions palatible.

ACKNOWLEDGEMENTS. This research was supported by the USDA NRI Competitive Grant 9202028 and the Office of Exploratory Research, United States EPA Project No. R819490-0.

\section{REFERENCES}

Asano S., Suzuki K., Hori H. \& Watanabe T. 1999: Synergistic effects of supernatants from Serratia marcescens culture on larvicidal activity of Bacillus thuringiensis CrylC toxin against common cutworm, Spodoptera litura. J. Pestic. Sci. 24: 44-48.

ATLAS R.M. 1988. Interactions between microorganisms and humans. In: Microbiology, Fundamentals and Applications. McMillan Publishing Co., New York, NY, pp. 537-566.

Beegle C.C., Lewis L.C., Lynch R.E. \& Martinez A.J. 1981: Interaction of larval age and antibiotic on the susceptibility of three insect species Trichoplusia ni, Heliothis virescens, and Ostrinia nubilalis to Bacillus thuringiensis. J. Invert. Pathol. 37: 143-153.

Brenner D.J. 1992: The Enterobacteriaceae. In: Holt J.G \& Krieg N.R. (eds): Bergey's Manual of Determinative Bacteriology. Williams \& Wilkins Co., Baltimore, MD, pp. 402-516.

Benort T.G., Wilson G.R., Pryor N. \& Bull D.L. 1990: Isolation and pathogenicity of Serratia marcescens from adult house flies infected with Entomophthora muscae. J. Invert. Pathol. 55: 142-144.
Bracken G.K. \& BuCher G.E. 1967: Mortality of hymenopterous parasite caused by Serratia marcescens. J. Invert. Pathol. 9: 130-132.

CHADWICK J.S. 1971: An assessment of the ability of individual moieties of Pseudomonas aeruginosa endotoxin to induce immunity in larvae of Galleria mellonella. J. Invert. Pathol. 17: 299-300.

Christensen B.M., Lafond M.M. \& Christensen L.A. 1986: Defense reactions of mosquitoes to filarial worms: effect of host age on the immune response to Dirofilaria immitis microfilariae. J. Parasitol. 72: 212-215.

DUNN P.E. \& DRAKE D.R. 1983: Fate of bacteria injected into naive and immunized larvae of the tobacco horn worm, Manduca sexta. J. Invert. Pathol. 41: 77-85.

El Sanousi S.M., El Sarag M.S.A. \& Mohamed S.E. 1987: Properties of Serratia marcescens isolated from diseased honey bees (Apis mellifera) larvae. J. Gen. Microbiol. 133: 215-219.

FAY H.C. 1989. Multihost Species of Fruit Flies. In: Robinson A.S. \& G. Hooper (eds): Fruit Flies, Their Biology, Natural Enemies and Control. Vol. 3B. Elsevier, Amsterdam, The Netherlands, pp. 121-129.

Felton G.W. \& Dahlman D.L. 1984: Allelochemical induced stress: effects of L-canavanine on the pathogenicity of Bacillus thuringiensis in Manduca sexta. J. Invert. Pathol. 44: 187-191.

Grimont P.A.D. \& Grimont F. 1978: The genus Serratia. Anmu. Rev. Microbiol. 32: 221-248.

James R.R. \& Lighthart B.M. 1992: The effect of temperature, diet, and larval instar on the susceptibility of an aphid predator, Hippodamia convergens (Coleoptera: Coccinellidae), to the weak bacterial pathogen Pseudomonas fluorescens. $J$. Invert. Pathol. 60: 215-218.

JaCQues R.P., Neilson W.T.A. \& Huston F. 1969: A bloating disease of adults of the apple maggot. J. Econ. Entomol. 62: 850-851.

Jianyoung L., Tracy J.W. \& Christensen B.M. 1992: Relationship of hemolymph phenol oxidase and mosquito age in Aedes aegypti. J. Invert. Pathol. 60: 188-191.

KoDama R. \& Nakasum Y. 1971: Further studies on the pathogenic mechanism of bacterial diseases in gnotobiotic silkworm larvae. Res. Commun. Inst. Fermentation Osaka 5: 1-9.

KRIEG A. 1987: Diseases caused by bacteria and other prokaryotes. In: Fuxa J. \& Tanada Y. (eds): Epizootiology of Insect Diseases. John Wiley \& Sons, New York, NY, pp. 323-356.

Lauzon C.R., SJogren R.E., Wright S.E. \& Prokopy R.J. 1998: Attraction of Rhagoletis pomonella (Diptera: Tephritidae) flies to odor of bacteria: apparent confinement to specialized members of enterobacteriaceae. Environ. Entomol. 27: 885-857.

Lauzon C.R., SJogren R.E. \& Prokopy R.J. 2000: Enzymatic capabilities of bacteria associated with apple maggot flies: a postulated role in attraction. $J$. Chem. Ecol. 26: 953-967.

LightHART B. 1988: Some changes in gut bacterial flora of fieldgrown Periodroma saucia (Lepidoptera: Noctuidae) when brought into the laboratory. Appl. Environ. Microbiol. 54: 1896-1898.

Lighthart B., Sewall D. \& Thomas D.R. 1988: Effect of several stress factors on the predatory mite, Metaseiulus occidentalis (Acari: Phytoseiidae), to the weak bacterial pathogen Serratia marcescens. J. Invert. Pathol. 52: 33-42.

LySENKo O. 1976: Chitinase of Serratia marcescens and its toxicity to insects. J. Invert. Pathol. 27: 385-386. 
LySENKO O. 1985: Non-sporeforming bacteria pathogenic to insects: incidence and mechanisms. Annu. Rev. Microbiol. 39 673-695.

Ourth D.D. \& Smalley D.L. 1980: Phagocytic and humoral immunity of the adult cotton boll weevil, Anthonomus grandis (Coleoptera: Curculionidae) to Serratia marcescens. $J$. Invert. Pathol. 36: 104-112.

PodGwatte J.D. \& Cosenza B.J. 1976: A strain of Serratia marcescens pathogenic for larvae of Lymantria dispar: Infectivity and mechanisms of pathogenicity. J. Invert. Pathol. 27: 199-208.
Poinar G.O., WassinK H.J.M. (JR.), Leegwater-VAn-Der Linden M.E. \& Van Der Geest L.P.S. 1979: Serratia marcescens as a pathogen of tsetse flies. Acta Trop. 36: 223-227.

SAS InstituTe 1985: Statistix Analytical Software. SAS Institute, Cary, N.C.

Steinhaus E.A. 1959: Serratia marcescens Bizio as an insect pathogen. Hilgardia 28: 351-380.

SteINHAUS E.A. 1963: Nonsporulating bacterial pathogens. In Insect Pathology, An Advanced Treatise. Vol. 2. Academic Press Inc., San Diego, CA, pp. 117-147.

Received October 9, 2001; revised September 6, 2002; accepted October 14, 2002 